\title{
Development of Ultra Fast Liquid Chromatography (UFLC) Method for Fluorescence Detection of Domperidone in Human Serum and Application to Pharmacokinetic Study
}

\author{
Chinna Reddy Palem, Satyanarayana Goda, Narendar Reddy Dudhipala, \\ Madhusudan Rao Yamsani* \\ National Facilities in Engineering and Technology with Industrial Collaboration (NAFETIC) Centre, University \\ College of Pharmaceutical Sciences, Kakatiya University, Warangal, India \\ Email: "pcreddy147@yahoo.co.in
}

Received 19 November 2015; accepted 15 January 2016; published 19 January 2016

Copyright (C) 2016 by authors and Scientific Research Publishing Inc.

This work is licensed under the Creative Commons Attribution International License (CC BY). http://creativecommons.org/licenses/by/4.0/

\section{(c) (i) Open Access}

\begin{abstract}
A simple and sensitive fluorescence detection of domperidone by ultra fast liquid chromatographic method was developed and validated in human serum. For the evaluation of new drug delivery systems, conducting of pharmacokinetic studies in human volunteers is essential for approval to marketing after preclinical evaluation in animal models. The present method consists of protein precipitation, extraction of analytes from human serum into dichloromethane and separation using reversed-phase $\mathrm{C}_{18}$ column. Propranolol hydrochloride was used as an internal standard and the eluent was monitored by fluorescence detector at excitation 282 and emission $328 \mathrm{~nm}$. The mobile phase used was 62:38 ratio of $10 \mathrm{mM}$ phosphate buffer pH adjusted to 3.1 with OPA and methanol at a flow rate of $1 \mathrm{~mL} \cdot \mathrm{min}^{-1}$. The method was evaluated for assay, LLOD, LLOQ, recovery and stability studies. The retention times for domperidone and propranolol hydrochloride were found to be $\mathbf{6 . 3 6}$ and $\mathbf{7 . 9 4}$ minutes respectively. The intraday and inter-day coefficient of variation and percent error values of assay method were less than 5\%; mean recovery was more than $96 \%$ for each analyte and the method was found to be precise, accurate and specific during study. The method was successfully applied for pharmacokinetic study of immediate and controlled release bioadhesive hot melt extruded buccal patches of domperidone after buccal administration to healthy human volunteers. The $\mathrm{C}_{\max }, \mathrm{T}_{\max }$ and $\mathrm{AUC}_{0-24}$ of domperidone from immediate and controlled release buccal patches were found to be $129.7 \mathrm{ng} \cdot \mathrm{mL}^{-1}, 1.5 \mathrm{~h}, 455.1 \mathrm{ng} \cdot \mathrm{h} \cdot \mathrm{mL}^{-1} \mathrm{and}^{145.7}$
\end{abstract}

${ }^{*}$ Corresponding author.

How to cite this paper: Palem, C.R., Goda, S., Dudhipala, N.R. and Yamsani, M.R. (2016) Development of Ultra Fast Liquid Chromatography (UFLC) Method for Fluorescence Detection of Domperidone in Human Serum and Application to Pharmacokinetic Study. American Journal of Analytical Chemistry, 7, 12-21. http://dx.doi.org/10.4236/ajac.2016.71002 
$\mathrm{ng} \cdot \mathrm{mL}^{-1}, 5.25 \mathrm{~h}, 911.0 \mathrm{ng} \cdot \mathrm{h} \cdot \mathrm{mL}^{-1}$ respectively. A simple, sensitive and reliable method for the fluorescence determination of domperidone in human serum by UFLC method was developed and validated.

\title{
Keywords
}

\author{
Domperidone, Ultra Fast Liquid Chromatography, Fluorescence, Human Serum, Buccal Patches, \\ Pharmacokinetics
}

\section{Introduction}

Domperidone (DOM) is a dopamine-receptor $\left(\mathrm{D}_{2}\right)$ antagonist. Chemically, 5-chloro-1-[1-[3-(2-oxo-2,3-dihydro$1 H$-benzimidazol-11-yl)propyl]-piperidin-4-yl]-1,3-dihydro-2H-benzimidazol-2-one and Propranolol $\mathrm{HCl}(\mathrm{PH})$ is 1-naphthalen-1-yloxy-3-(propan-2-ylamino) propan-2-ol; hydrochloride. It is widely used in the treatment of motion-sickness, increasing lower esophageal sphincter pressure, further preventing nausea and vomiting and also prompting gastrointestinal motility [1]. In humans, peak plasma levels of domperidone occur within 10 to 30 min following intra muscular injection and $30 \mathrm{~min}$ after oral (fasted) administration. It was reported to be rapidly absorbed after oral administration, but undergone extensive first pass metabolism, leading to poor bioavailability of $15 \%$ [2].

An accurate measurement of low concentrations of DOM in serum method is necessary for pharmacokinetic studies. Literature survey reveals that several simultaneous methods have been used for quantification of DOM using high-performance liquid chromatography (HPLC) in tablet formulation [3]-[7]; in rat serum samples using HPLC with fluorescence detection [8], in human serum and human breast milk by electrospray mass spectrometry and by fluorescence detector [9] [10] and ${ }^{14} \mathrm{C}$-labelled radio activity method for excretion and metabolism in animals and men [11]. Previously, liquid chromatography tandem mass spectrometry chromatographic method in human plasma [12] [13] and spectroscopic study for conformational analysis [14] was reported. The drug metabolites in plasma have been determined by LC-ESI-MS/MS in human plasma and urine samples of gastroparesis patients [15]. Among the available various methods, the HPLC method seems convenient, reliable, and reproducible and as minimal sample preparation required.

The content of the present work was to develop and optimize a simple ultra fast liquid chromatography (UFLC) method with fluorescence detection for the determination of DOM in human serum was developed. For the evaluation of new drug delivery systems like buccal drug delivery systems, conducting of pharmacokinetic studies in human volunteers is essential for approval to marketing after preclinical evaluation in animal models. The advantages of present method include simple and single step extraction procedure using inexpensive chemicals, and short run time. The present method was also successfully applied for the study of pharmacokinetics of DOM from bioadhesive buccal patches in humans. The chemical structure of domperidone and propranolol hydrochloride as an internal standard is shown in Figure 1.

\section{Experimental}

\subsection{Materials}

Domperidone (DOM) and propranolol hydrochloride (PH) pure samples were gifted respectively by Torrent pharmaceuticals, Baroda, India. Acetonitrile, methanol (HPLC) and potassium dihydrogen orthophosphate, ortho phosphoric acid (GR) and sodium hydroxide were purchased from Merck, Mumbai, India. Double distilled water was used during the entire HPLC procedure.

\subsection{Chromatographic Conditions}

Analysis of samples was performed using UFLC. The UFLC system (Shimadzu, Kyoto, Japan) consisted of two LC-20AD Prominence liquid chromatograph pumps, RF-10AXL, Fluorescence detector, CTO-20AC Prominence column oven with Lab solutions (LC solutions) software. The analytical column used was Onyx monolithic C18 column (Phenomenex, $100 \mathrm{~mm}^{2} 4.6 \mathrm{~mm}$ i.d, particle size $5 \mu$ ) at $25^{\circ} \mathrm{C}$ temperature. The mobile phase 


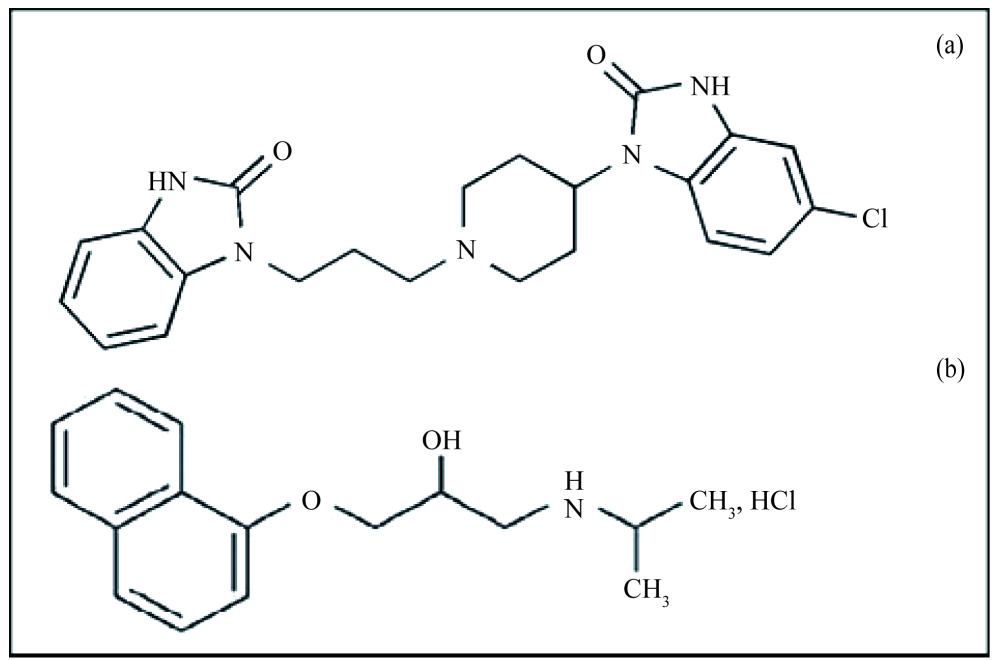

Figure 1. Structures of domperidone (a) and propranalol hydrochloride (b).

used was a mixture of (62:38) of $10 \mathrm{mM}$ phosphate buffer $\mathrm{pH}$ adjusted to 3.1 with OPA and methanol. The flow rate was $1 \mathrm{~mL} \cdot \mathrm{min}^{-1}$ and detection was carried out at excitation 282 and emission $328 \mathrm{~nm}$. The injection volume was $20 \mu \mathrm{L}$ and detector sensitivity was set to 0.0005 AUFS.

\subsection{Preparation of Calibration Standards and Quality Control (QC) Samples}

Initially, the stock solutions of DOM and PH were prepared in methanol at a concentration of $100 \mu \mathrm{g} \cdot \mathrm{mL}^{-1}$ each. PH (Figure 1(b)) was used as an internal standard (IS). The working solutions of $10 \mathrm{ng} \cdot \mathrm{mL}^{-1}$ to $10 \mu \mathrm{g} \cdot \mathrm{mL}^{-1}$ for DOM and $1.5 \mu \mathrm{g} \cdot \mathrm{mL}^{-1}$ for PH were prepared by appropriately diluting the respective stock solutions. DOM working solutions were used to prepare the spiking stock solutions for construction of calibration curve at a concentration of $10-10,000 \mathrm{ng} \cdot \mathrm{mL}^{-1}$. QC samples at three different levels for DOM (15, 4750 and 9500 $\left.\mathrm{ng} \cdot \mathrm{mL}^{-1}\right)$ were prepared. All the stock solutions were refrigerated $\left(4^{\circ} \mathrm{C}\right)$ when not in use. Calibration standards and QC samples were prepared in bulk by spiking $100 \mu \mathrm{L}$ of respective spiking stock solutions to $1 \mathrm{~mL}$ of control human serum and were stored at $-20^{\circ} \mathrm{C}$ until analysis.

\subsection{Sample Preparation for Analysis}

Aliquot $(1 \mathrm{~mL})$ of human serum containing DOM was transferred into screw capped tubes and $100 \mu \mathrm{L}$ of an IS (1500 $\mathrm{ng} \cdot \mathrm{mL}^{-1}$ of $\mathrm{PH}$ ) was added and vortexed for $2 \mathrm{~min}$. Acetonitrile $7 \mathrm{~mL}$ was added, vortexed for $2 \mathrm{~min}$. This was centrifuged at $6000 \mathrm{rpm}$ for $15 \mathrm{~min}$. The organic layer was separated and allowed to evaporate in vacuum oven (Sheldon Manufacturing Inc., Cornelius, USA). The evaporated residue was reconstituted with $100 \mu \mathrm{L}$ of mobile phase and $20 \mu \mathrm{L}$ of the reconstituted sample was injected into HPLC system.

\subsection{Assay Validation}

The intra-day and inter-day precision and accuracy of the assay was determined by percent coefficient of variation (CV) and percent relative error (RE) values respectively, based on reported guidelines [16]. Samples containing 15, 4750 and $9500 \mathrm{~mL}^{-1}$ of DOM were spiked for the determination of precision and accuracy. Five replicates at each concentration were processed as described above on days 1, 3, 5 and 10 to determine intra-day and inter-day precision and accuracy. The percent CV and percent RE values were calculated using following equations:

Percent $\mathrm{CV}=(\mathrm{SD} /$ mean $) \times 100$

Percent $\mathrm{RE}=[($ Measured value - True value $) /$ True value $] \times 100$

\subsection{Low Limit of Quantitation (LLOQ) and Limit of Detection (LOD)}

The lowest concentration of analyte that can be determined with precision and accuracy of acceptable range is 
expressed as LLOQ. Parameter that provides the lowest concentration in a sample that can be detected from background noise but not quantitated is the LOD of a molecule. LOD was determined using signal-to-noise ratio $(\mathrm{s} / \mathrm{n})$ of 3:1 by comparing test results from samples with known concentrations of analytes with blank samples.

\subsection{Recovery}

The recovery of DOM was determined for QC samples at concentration of 15, 4750 and $9500 \mathrm{~mL}^{-1}$. Five replicates of each QC sample were extracted and injected into UFLC system. The extraction recovery at each concentration was calculated using following equation:

Recovery $=($ Peak area after extraction $/$ Peak area after direct injection $) \times 100$

\subsection{Stability Studies}

To ensure the reliability of results in handling and storing of serum samples and stock solutions, stability studies were carried out at three concentration levels of DOM, 15, 4750 and $9500 \mathrm{~mL}^{-1}$. The stability of spiked human serum stored at room temperature (bench top stability) was evaluated for $12 \mathrm{~h}$. Freeze and thaw stability was performed over three freeze-thaw cycles by thawing at room temperature for $2-8 \mathrm{~h}$ and then refreezing at $-20^{\circ} \mathrm{C}$ for $12-24 \mathrm{~h}$. The long-term stability of DOM in human serum was assessed by carrying out the experiment after 30 days of storage at $-20^{\circ} \mathrm{C}$. The stock solution stability of DOM $\left(100 \mu \mathrm{g} \cdot \mathrm{mL}^{-1}\right.$ for each $)$ was determined at room temperature for $12 \mathrm{~h}$ and upon refrigeration $\left(4^{\circ} \mathrm{C}\right)$ for 14 days. The concentration of DOM after each storage period was related to the initial concentration as determined for the samples that were freshly prepared.

\subsection{Robustness}

To determine the robustness of the method, the final experimental conditions were altered and the results were examined. The flow rate was varied by $1 \pm 0.2 \mathrm{~mL} \cdot \mathrm{min}^{-1}$. The percentage of organic strength was varied by $62 \%$ $\pm 2 \%$. Buffer concentration was varied by $10 \pm 5 \mathrm{mM}$, pH varied by $3.1 \pm 0.2$ units and column temperature was varied by $40^{\circ} \mathrm{C} \pm 5^{\circ} \mathrm{C}$.

\subsection{Application to Pharmacokinetic Study}

The pharmacokinetic study was conducted in twelve healthy male volunteers. The study protocol was reviewed and approved by the institutional human ethical committee, University College of Pharmaceutical Sciences, Kakatiya University, Warangal, India. The bioadhesive hot melt extruded immediate release and controlled release buccal Patches (HME IR and HME CR) was compared with marketed tablet (Domstal). The volunteers participated in the study were non-alcoholic and had no medication for two weeks prior to the study. Volunteers were allowed free access to food and water, until the night prior to dosing and were fasted for $10 \mathrm{~h}$.

Latin square cross over design was followed; Volunteers were divided into two groups, each group consisting of six volunteers. To one group, marketed tablet was administered and bioadhesive HME buccal patches to another group in first phase. In second phase vice versa was followed and was conducted after 2 weeks of wash out period. Blood samples ( $5 \mathrm{~mL}$ ) were collected at preset time intervals of 0, 0.25, 0.5, 1, 1.5, 2, 4, 8, 12 and 24 for HME IR patch and 0.5, 1, 1.5, 2, 4, 6, 8, 12 and 24 for HME CR patch. All blood samples were allowed to clot and centrifuged for $10 \mathrm{~min}$ at $5000 \mathrm{rpm}$ (MIKRO 220R, Hettich, Germany). The serum was separated and transferred into clean micro-centrifuge tubes and stored at $-20^{\circ} \mathrm{C}$ until UFLC analysis. The amount of DOM in the samples was estimated using UFLC.

Pharmacokinetic parameters, peak serum concentration $\left(\mathrm{C}_{\max }\right)$, time to reach peak concentration $\left(\mathrm{T}_{\max }\right)$ and area under the curve (AUC) for DOM was obtained for each volunteer using a computer program KINETICA 2000 (Version 3.0, Innaphase Corporation, Philadelphia, USA) meant for calculation of model independent parameters.

\section{Results and Discussion}

\subsection{Chromatography}

The chromatographic conditions and sample preparation for the proposed method were optimized to suit the pharmacokinetic studies. Figure 2 shows typical chromatograms of human blank serum (drug free), serum 


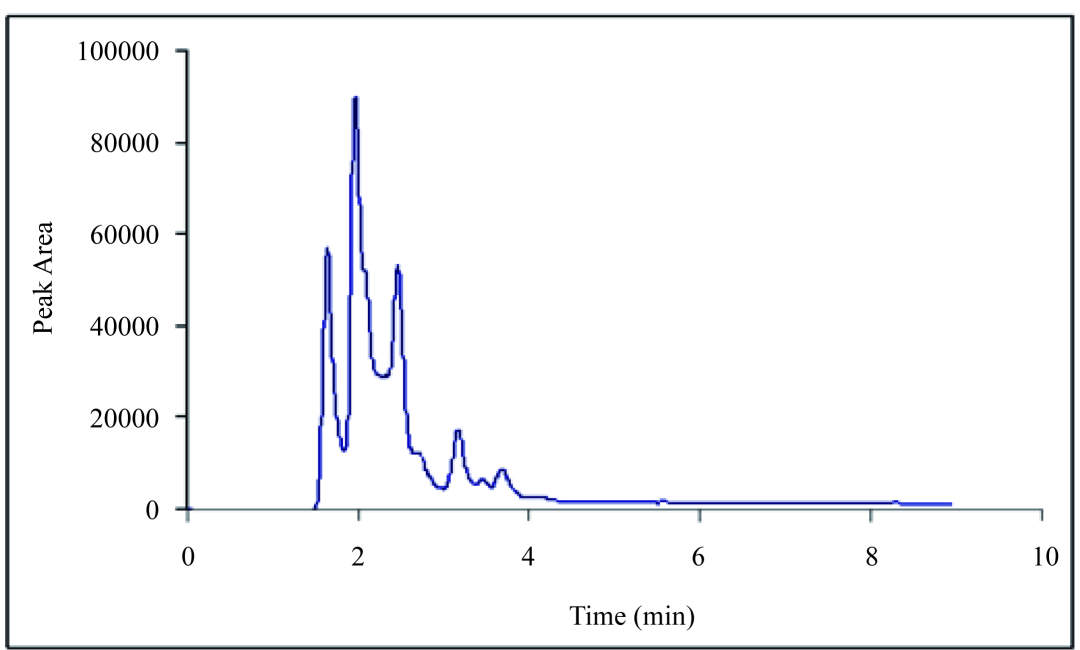

(a)

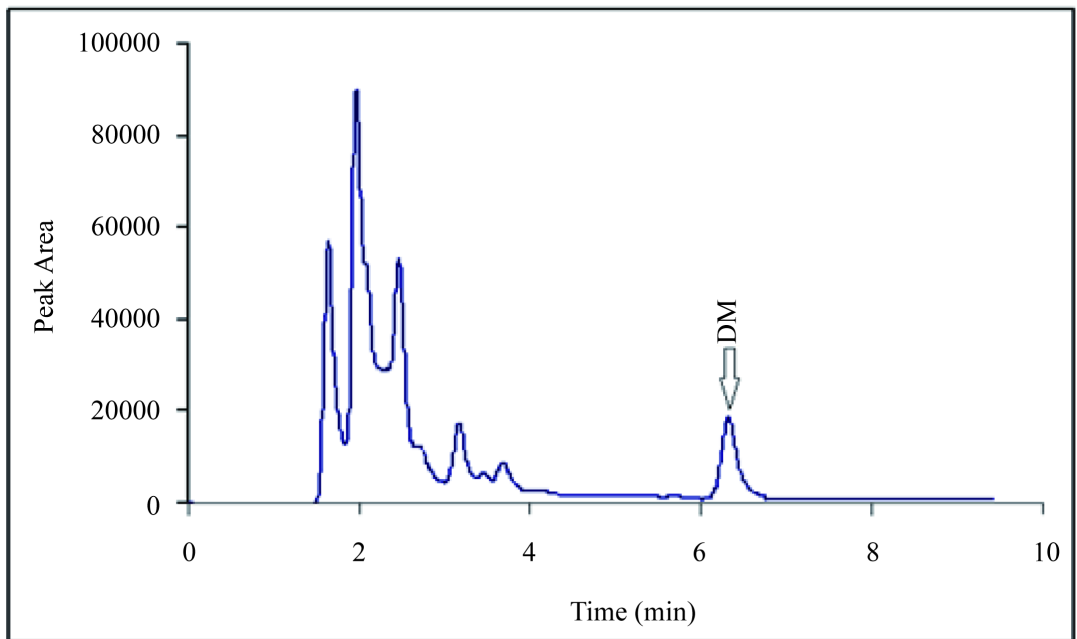

(b)

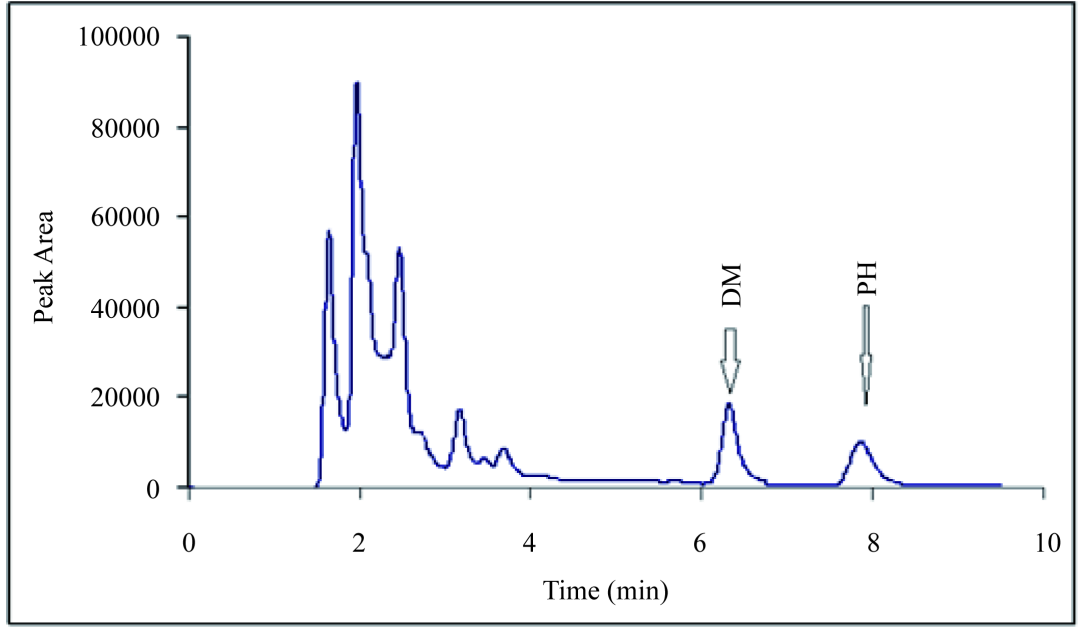

(c)

Figure 2. Representative chromatograms of human blank serum (a), drug spiked with serum (b) and drug and internal standard spiked with serum after administration of buccal patch (c). 
spiked with DOM; human serum after buccal administration of DOM HME patches dosage form. The retention times of DOM and PH respectively were found to be 6.36 and 7.94 minutes respectively with a total run time of $10 \mathrm{~min}$. The analytical process of DOM and IS were resolved with good symmetry. At the retention times of drug and IS, no endogenous interfering peaks were observed in individual human blank serum, hence, thereby confirming the specificity of the analytical method. System suitability parameters for the method were as follows: theoretical plates for DOM and IS were 1684 and 1821 respectively. Tailing factor were 1.2 and 1.5 respectively for DOM and PH. Resolution between DOM and IS was 2.4.

\subsection{Quantification and Calibration Curve}

For the quantification of DOM in human serum, the ratio of peak area of DOM to IS was used. The calibration curves of DOM was constructed over a period of 10 - 12 days, each time the calibration curve originating from a new set of extractions. Linear relationship was observed between the concentration of DOM and the peak area of DOM with a correlation coefficient $\left(r^{2}=0.999\right)$. The regression equation is $y=m x+c$, where y represents the peak area ratio of DOM to IS, $x$ represents the concentrations of DOM, $m$ is slope of the curve and $c$ is the intercept.

\subsection{Accuracy and Precision}

The required studies were carried out to estimate the precision and accuracy of the UFLC method. The accuracy and precision of the method were evaluated for DOM analytes with QC samples at concentrations of 15, 4750 and $9500 \mathrm{ng} \cdot \mathrm{mL}^{-1}$. The inter-day accuracy and precision were determined on four different days and the results are shown in Table 1 . The inter-day and intra-day precisions of the QC samples for DOM were satisfactory with $\mathrm{CV}$ and \% RE was found to be less than $5 \%$ and $3.5 \%$, respectively.

\subsection{LLOQ and LOD}

LLOQ was established by determining the concentrations of four spiked calibration standards. The LLOQ of the method was found to be $0.25 \mathrm{ng} \cdot \mathrm{mL}^{-1}$ with CV less than $10 \%$ and an accuracy of $93 \%-100 \%$. The LOD was determined to be $0.50 \mathrm{ng} \cdot \mathrm{mL}^{-1}$ for DOM based on a signal to noise $(\mathrm{s} / \mathrm{n})$ ratio of 2:1.

\subsection{Recovery}

The extraction recovery was determined by standard addition at three different concentrations 15, 4750, 9500 $\mathrm{ng} \cdot \mathrm{mL}^{-1}$, one concentration (1500 $\mathrm{ng} \cdot \mathrm{mL}^{-1}$ ) for IS. The extraction recovery was calculated by comparing the peak areas of the prepared standard samples with those of standard solutions; the results are shown in Table 2. The extraction recovery of DOM at 15,4750 and $9500 \mathrm{ng} \cdot \mathrm{mL}^{-1}$ was $98.5 \%, 98.3 \%$ and $98.3 \%$. The mean recovery of PH was found to be $97.3 \%$. The recovery of DOM from the human serum samples was consistent and efficient with using the above described procedure.

\subsection{Stability}

The stability of stock solutions was performed at $1000 \mathrm{ng} \cdot \mathrm{mL}^{-1}$ of DOM. After storage for 14 days at $4^{\circ} \mathrm{C}$ and at room temperature for $12 \mathrm{~h}$, more than 99\% of DOM remained unchanged, based on peak areas in comparison with freshly prepared solution. The results suggest that DOM in stock solutions were stable for at least 14 days when stored at $4^{\circ} \mathrm{C}$ and for $12 \mathrm{~h}$ at room temperature. Bench top stability of DOM in serum was investigated and

Table 1. Intra-day and inter-day precision and accuracy data for assay of DOM in human serum $(n=6)$.

\begin{tabular}{|c|c|c|c|c|c|c|}
\hline \multirow{2}{*}{ Added conc $\left(\mathrm{ng} \cdot \mathrm{mL}^{-1}\right)$} & \multicolumn{2}{|c|}{ Calculated conc $\left(\mathrm{ng} \cdot \mathrm{mL}^{-1}\right)$} & \multicolumn{2}{|c|}{$\% \mathrm{CV}$} & \multicolumn{2}{|c|}{ \% Relative error } \\
\hline & Intra day & Inter day & Intra day & Inter day & Intra day & Inter day \\
\hline 15 & 14.91 & 14.89 & 14.84 & 14.82 & 0.8 & -1.6 \\
\hline 4750 & 4748.2 & 2743.6 & 5.2 & 4.3 & -2.4 & -0.9 \\
\hline 9500 & 9501.4 & 9493.6 & 4.1 & 2.8 & 0.8 & -1.4 \\
\hline
\end{tabular}


the results revealed that DOM in serum were stable with an average percentage of 97.8, 98.9, 100.2. The repeated freezing and thawing for three cycles of serum samples spiked with DOM, showed a mean percentage concentration of 96,99 and 100 . Long-term stability of the DOM in serum at $-20^{\circ} \mathrm{C}$ showed a mean percentage concentration of 95, 98.8, and 99.6. The results (Table 3) of stability study indicated that DOM was stable in the studied conditions.

\subsection{Robustness}

The results of robustness study are shown in Table 4. It can be seen that every employed condition, the chromatographic parameters are in accordance with established value [16]. In all the employed conditions, the tailing factor for DOM and PH was found to be less than 1.4 and all analytes were well separated under the changes carried out. The resolution ranged between DOM and IS was 2.9 - 3.8. Considering the result of modifications in the system suitability parameters and the specificity of the method, it would be concluded that the method conditions are robust.

\subsection{Application to Pharmacokinetic Study}

The method was applied to the analysis of serum samples obtained after buccal administration of a hot melt extruded immediate and controlled release buccal patches in healthy human volunteers. Figure 3(a), Figure 3(b) depicts the mean serum profiles of DOM after administration of buccal route. The pharmacokinetic parameters estimated were shown in Table 5. The $\mathrm{C}_{\max }, \mathrm{T}_{\max }, \mathrm{AUC}_{0-24}$ and $\mathrm{AUC}_{\text {Total }}$ for DOM after administration of IR and CR buccal patch were found to be $129.7 \mathrm{ng} \cdot \mathrm{mL}^{-1}, 1.5 \mathrm{~h}, 455.1 \mathrm{ng} \cdot \mathrm{h} \cdot \mathrm{mL}^{-1}$ and $145.7 \mathrm{ng} \cdot \mathrm{mL}^{-1}, 5.25 \mathrm{~h}, 911.0$ $\mathrm{ng} \cdot \mathrm{h} \cdot \mathrm{mL}^{-1}$ respectively.

Table 2. Recovery and accuracy of the proposed method.

\begin{tabular}{cccccccc}
\hline \multirow{2}{*}{$\begin{array}{c}\text { Conc } \\
\left(\mathbf{n g} \cdot \mathbf{m L}^{-1}\right)\end{array}$} & $\begin{array}{c}\text { Absolute recovery } \\
\text { Conc }\left(\mathbf{n g} \cdot \mathbf{m L}^{-1}\right) \\
(\mathbf{M e a n} \pm \mathbf{S D})\end{array}$ & $\begin{array}{c}\text { Mean (\%) } \pm \text { S.D } \\
(\mathbf{n}=\mathbf{5})\end{array}$ & $\begin{array}{c}\text { Range } \\
(\text { Min-Max) }\end{array}$ & \% CV & $\begin{array}{c}\text { Mean } \pm \text { SD } \\
(\mathbf{n}=\mathbf{5})\end{array}$ & $\begin{array}{c}\text { Range } \\
(\mathbf{M i n}-\mathbf{M a x})\end{array}$ & \% CV \\
\hline 15 & $14.98 \pm 0.03$ & $98.5 \pm 1.7$ & $95.1-99.2$ & 2.4 & $96.8 \pm 2.7$ & $92.4-99.2$ & 3.4 \\
4750 & $4743.2 \pm 48.3$ & $98.3 \pm 3.1$ & $92.5-99.4$ & 2.8 & $97.1 \pm 2.3$ & $94.9-98.9$ & 2.1 \\
9500 & $9495.7 \pm 121.4$ & $98.9 \pm 2.3$ & $94.2-101.8$ & 3.01 & $95.6 \pm 2.4$ & $92.2-98.7$ & 2.6 \\
\hline
\end{tabular}

Table 3. Stability study results of the proposed method.

\begin{tabular}{|c|c|c|c|c|c|c|}
\hline \multirow{2}{*}{ Stability } & \multirow{2}{*}{$\begin{array}{l}\text { Spiked conc } \\
\left(\mathbf{n g} \cdot \mathrm{mL}^{-1}\right)\end{array}$} & \multicolumn{2}{|c|}{$\begin{array}{l}\text { Calculated comparison sample } \\
\text { concentration }\left(\mathrm{ng} \cdot \mathrm{mL}^{-1}\right)^{\mathrm{d}}\end{array}$} & \multicolumn{2}{|c|}{$\begin{array}{l}\text { Calculated stability sample } \\
\text { concentration }\left(\mathrm{ng} \cdot \mathrm{mL}^{-1}\right)^{\mathbf{d}}\end{array}$} & \multirow[t]{2}{*}{ Avg \% } \\
\hline & & Mean \pm SD & $\% \mathrm{CV}$ & Mean \pm SD & $\% \mathrm{CV}$ & \\
\hline \multirow{3}{*}{ Bench top ${ }^{a}$} & 15 & $14.89 \pm 0.09$ & 3.8 & $14.86 \pm 0.15$ & 8.5 & 98 \\
\hline & 4750 & $4742.6 \pm 48.5$ & 2.5 & $4738.2 \pm 84.3$ & 3.2 & 98.5 \\
\hline & 9500 & $9484.7 \pm 103.4$ & 2.1 & $9435.3 \pm 122.4$ & 1.3 & 100 \\
\hline \multirow{3}{*}{ Freeze and thaw ${ }^{\mathrm{b}}$} & 15 & $14.94 \pm 0.1$ & 5.8 & $14.82 \pm 0.2$ & 8.4 & 96.4 \\
\hline & 4750 & $4746.4 \pm 86.3$ & 2.7 & $4743.8 \pm 57.8$ & 3.1 & 98.9 \\
\hline & 9500 & $9503.7 \pm 104.4$ & 1.9 & $9498.2 \pm 121.3$ & 1.5 & 100 \\
\hline \multirow{3}{*}{ Long term ${ }^{\mathrm{c}}$} & 15 & $14.88 \pm 0.1$ & 4.2 & $14.79 \pm 0.14$ & 5.2 & 97 \\
\hline & 4750 & $4748.5 \pm 72.6$ & 2.4 & $4745.3 \pm 62.3$ & 3.0 & 99 \\
\hline & 9500 & $9451.6 \pm 113.4$ & 2.6 & $9448.2 \pm 97.6$ & 1.7 & 99.5 \\
\hline
\end{tabular}

${ }^{\mathrm{a}}$ After $12 \mathrm{hr}$ at room temperature; ${ }^{\mathrm{b}}$ After three freeze thaw cycles; ${ }^{\mathrm{c}}$ After 30 days at $-20{ }^{\circ} \mathrm{C}$; ${ }^{\mathrm{d}}$ Values are mean \pm S.D $(\mathrm{n}=3$ ). 
Table 4. Robustness data of the developed HPLC method.

\begin{tabular}{|c|c|c|c|c|c|c|c|c|}
\hline \multirow{2}{*}{ Parameter } & \multirow{2}{*}{ Modification } & \multicolumn{2}{|c|}{ Retention time (min) } & \multicolumn{2}{|c|}{ Tailing factor } & \multicolumn{2}{|c|}{ Theoretical plates } & \multirow{2}{*}{$\begin{array}{l}\text { Resolution } \\
\text { DM \& PH }\end{array}$} \\
\hline & & DM & PH & DM & PH & DM & PH & \\
\hline \multirow{3}{*}{$\begin{array}{l}\text { Mobile phase ratio (v/v), } \\
\text { acetonitrile:buffer (pH 3.1) }\end{array}$} & $60: 40$ & 6.36 & 7.94 & 1.02 & 1.04 & 1722 & 1822 & 3.2 \\
\hline & $62: 38$ & 5.88 & 6.43 & 1.01 & 0.96 & 1719 & 1835 & 3.5 \\
\hline & $64: 36$ & 4.84 & 6.02 & 1.03 & 1.04 & 1421 & 1254 & 3.1 \\
\hline \multirow{3}{*}{ Flow rate $\left(\mathrm{mL} \cdot \mathrm{min}^{-1}\right)$} & 0.8 & 6.35 & 7.92 & 1.02 & 1.13 & 2748 & 2684 & 3.6 \\
\hline & 1.0 & 5.82 & 6.42 & 1.11 & 1.04 & 1123 & 1738 & 2.9 \\
\hline & 1.2 & 4.84 & 5.12 & 0.94 & 1.12 & 2692 & 2103 & 3.0 \\
\hline \multirow{3}{*}{ Buffer concentration (mM) } & 10 & 6.35 & 7.94 & 1.12 & 1.09 & 1114 & 1836 & 3.3 \\
\hline & 5 & 6.12 & 7.26 & 1.10 & 0.98 & 1816 & 1847 & 3.6 \\
\hline & 15 & 4.93 & 6.17 & 1.03 & 1.02 & 1919 & 1843 & 3.8 \\
\hline \multirow{3}{*}{$\mathrm{pH}$} & 10 & 6.36 & 7.94 & 1.00 & 1.02 & 1831 & 1812 & 3.2 \\
\hline & 5 & 6.23 & 7.88 & 1.04 & 1.01 & 1054 & 1825 & 3.5 \\
\hline & 15 & 6.24 & 7.83 & 0.99 & 1.10 & 1735 & 1835 & 3.6 \\
\hline \multirow{3}{*}{ Temperature in ${ }^{\circ} \mathrm{C}$} & 35 & 6.36 & 7.94 & 1.15 & 1.15 & 1728 & 1846 & 3.3 \\
\hline & 40 & 5.87 & 6.45 & 1.06 & 1.11 & 1094 & 1849 & 3.8 \\
\hline & 45 & 4.87 & 6.12 & 1.13 & 1.13 & 1635 & 1746 & 3.1 \\
\hline
\end{tabular}

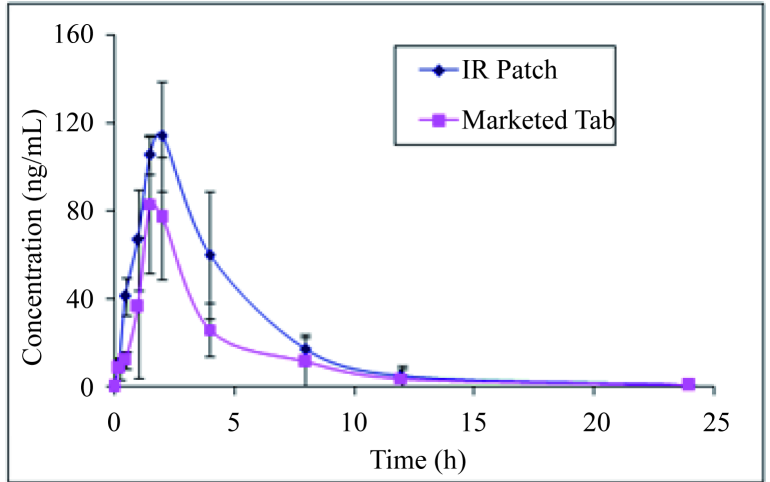

(a)

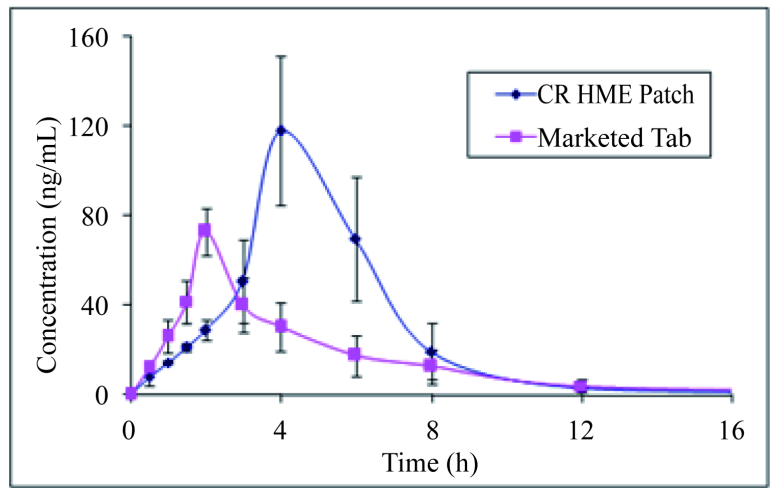

(b)

Figure 3. Mean serum concentration vs time profiles of domperidone after HME immediate and controlled release buccal patches compared to marketed tablet (mean $\pm \mathrm{SD}, \mathrm{n}=6$ ).

Table 5. Pharmacokinetic parameters of HME immediate and controlled release DOM buccal patches after buccal administration to human volunteers (mean $\pm S D, n=6$ ).

\begin{tabular}{ccc}
\hline Parameter & IR & CR \\
\hline $\mathrm{C}_{\max }\left(\mathrm{ng} \cdot \mathrm{mL}^{-1}\right)$ & $129.7 \pm 24.5$ & $145.7 \pm 19.2$ \\
$\mathrm{~T}_{\max }(\mathrm{h})$ & $1.5 \pm 0.26$ & $5.15 \pm 1.03$ \\
$\mathrm{AUC}_{0-24}\left(\mathrm{ng}-\mathrm{h} \cdot \mathrm{mL}^{-1}\right)$ & $455.1 \pm 114$. & $911.0 \pm 77.8$ \\
\hline
\end{tabular}




\section{Conclusion}

A simple, sensitive and reliable method for the fluorescence determination of domperidone over the concentration range of $10-10,000 \mathrm{ng} \cdot \mathrm{mL}^{-1}$, in human serum by UFLC was developed and validated. The method consisted of sample preparation by protein precipitation and extraction into acetonitrile, followed by chromatographic separation and fluorescence detection. No interfering peaks were observed at the elution times of domperidone and IS. The method was accurate, reproducible, specific and applicable to the evaluation of pharmacokinetic profiles of domperidone in humans.

\section{Acknowledgements}

One of the authors (Dr. Palem Chinna Reddy) thank University Grant Commission (UGC), New Delhi for providing project fellow under UGC major research project [F.No: 32-134/2006(SR)].

\section{References}

[1] Sweetman, S.C. (2007) Martindale: The Complete Drug Reference. Pharmaceutical Press, London, 1556-1557.

[2] Brogden, R.N., Carmine, A.A., Heel, R.C., Speight, T.M. and Avery, G.S. (1982) Domperidone. A Review of Its Pharmacological Activity, Pharmacokinetics and Therapeutic Efficacy in the Symptomatic Treatment of Chronic Dyspepsia and as an Antiemetic. Drugs, 24, 360-400. http://dx.doi.org/10.2165/00003495-198224050-00002

[3] Siva Subramanian, L. and Kumar, A.V. (2007) Simultaneous HPLC Estimation of Omeprazole and Domperidone from Tablets. Indian Journal of Pharmaceutical Sciences, 69, 674-676. http://dx.doi.org/10.4103/0250-474X.38474

[4] Zarapakar, S.S. and Kanyawar, N.S. (2004) Simultaneous Estimation of Domperidone and Omeprazole in Pharmaceutical Dosage by RP-HPLC. Indian Drugs, 39, 217-221.

[5] Kanumula, G.V. and Raman, B. (2000) Simultaneous Determination of Ranitidine HCL and Domperidone in Pharmaceutical Dosage by RPHPLC. Indian Drugs, 37, 375-378.

[6] Karthik, A., Subramanian, G., Kumar, R.A. and Udupa, N. (2007) Simultaneous Estimation of Paracetamol and Domperidone in Tablets by Reverse Phase HPLC Method. Indian Journal of Pharmaceutical Sciences, 69, 142-144. http://dx.doi.org/10.4103/0250-474X.32132

[7] Sivakumar, T., Manavalan, R. and Valliappan, K. (2007) Development and Validation of a Reversed-Phase HPLC Method for Simultaneous Determination of Domperidone and Pantoprazole in Pharmaceutical Dosage Forms. Acta Chromatographica, 18, 130-142.

[8] Yamamoto, K., Hagino, M., Kotaki, H. and Iga, T. (1998) Quantitative Determination of Domperidone in Rat Plasma by High-Performance Liquid Chromatography with Fluorescence Detection. Journal of Chromatography B: Biomedical Sciences and Applications, 720, 51-55. http://dx.doi.org/10.1016/S0378-4347(98)00339-9

[9] Zavitsanos, A.P., MacDonald, C., Bassoo, E. and Gopaul. D. (1990) Determination of Domperidone in Human Serum and Human Breast Milk by High-Performance Liquid Chromatography-Electrospray Mass Spectrometry. Journal of Chromatography B: Biomedical Sciences and Applications, 730, 9-24. http://dx.doi.org/10.1016/S0378-4347(99)00163-2

[10] Yoshizato, T., Tsutsumi, K., Kotegawa, T., Imai, H. and Nakano, S. (2014) Determination of Domperidone in Human Plasma Using High Performance Liquid Chromatography with Fluorescence Detection for Clinical Application. Journal of Chromatography B, 961, 86-90. http://dx.doi.org/10.1016/j.jchromb.2014.05.004

[11] Meuldermans, W., Hurkmans, R., Swysen, E., Hendrickx, J., Michiels, M., Lauwers, W. and Heykants, W.J. (1981) On the Pharmacokinetics of Domperidone in Animals and Man III. Comparative Study on the Excretion and Metabolism of Domperidone in Rats, Dogs and Man. European Journal of Drug Metabolism and Pharmacokinetics, 6, 49-60. http://dx.doi.org/10.1007/BF03189515

[12] Smit, M.J., Sutherl, F.C.W., Humdt, H.K.T., Swart, K.J., Humdt, A.F. and Els, J. (2002) Rapid and Sensitive Liquid Chromatography Tandem Mass Spectrometry Method for the Quantitation of Domperidone in Human Plasma. Journal of Chromatography A, 949, 65-70. http://dx.doi.org/10.1016/S0021-9673(01)01553-9

[13] Wu, M.S., Gao, L., Cai, X.H. and Wang, G.J. (2002) Determination of Domperidone in Human Plasma by LC-MS and Its Pharmacokinetics in Healthy Chinese Volunteers. Acta Pharmacologica Sinica, 23, 285-288.

[14] Cignitti, M., Cotta Ramusino, M. and Rufini, L. (1995) UV Spectroscopic Study and Conformational Analysis of Domperidone. Journal of Molecular Structure, 350, 43-47. http://dx.doi.org/10.1016/0022-2860(94)08463-R

[15] Youssef, A.S., Argikar, U.A., Pathikonda, M., Parkman, H.P. and Nagar, S. (2013) Identification of Domperidone Me- 
tabolites in Plasma and Urine of Gastroparesis Patients with LC-ESI-MS/MS. Xenobiotica, 43, 1073-1083. http://dx.doi.org/10.3109/00498254.2013.797623

[16] Guidance for Industry (2001) Bioanalytical Method Validation. US Department of Health and Human Services, Food and Drug Administration, Center for Drug Evaluation and Research, Rockville. 